\title{
Plasmid-mediated Serum Resistance and Alterations in the Composition of Lipopolysaccharides in Salmonella dublin
}

\author{
By NOBUYUKI TERAKADO,$^{1 *}$ TAKAFUMI HAMAOKA ${ }^{1}$ AND \\ HIROFUMI DANBARA ${ }^{2}$ \\ ${ }^{1}$ National Institute of Animal Health, Tsukuba-Science City, Ibaraki 305, Japan \\ ${ }^{2}$ The Kitasato Institute, Minato-ku, Tokyo 108, Japan
}

(Received 30 December 1987; revised 11 March 1988)

\begin{abstract}
Survival rates of Salmonella dublin in rabbit serum after culture for $1 \mathrm{~h}$ at $37^{\circ} \mathrm{C}$ were compared between a wild-type strain (5240) carrying a $50 \mathrm{MDa}$ plasmid, a plasmid-cured strain (C524), and a cured strain containing the $50 \mathrm{MDa}$ plasmid tagged with Tn1 (5241). Strain C524 was more susceptible to the bactericidal activity of normal serum than its parent strain 5240 (percentage survival $<1 \%$ and $52.5 \pm 9.2 \%$, respectively). On the other hand, the percentage survival of strain 5241 was significantly increased $(90.4 \pm 4.0 \%)$, indicating that the reintroduction of the plasmid into the cured strain restored the serum resistance. Moreover, this change in the serum resistance properties correlated with changes in the neutral sugar composition of the lipopolysaccharides (LPS) of these strains, suggesting that the $50 \mathrm{MDa}$ plasmid is necessary for O-side chain expression in the LPS of S. dublin.
\end{abstract}

\section{INTRODUCTION}

Salmonella dublin is primarily associated with cattle; it causes acute diarrhoea, septicaemia and abortion in adult cattle and a chronic disease in calves (Walton, 1972). Milk-borne outbreaks of infection due to $S$. dublin have also been reported in man (Small \& Sharp, 1979; Fierer, 1983). In both cattle and man, the organism is highly invasive (Walton, 1972; Fierer, 1983).

In a previous report (Terakado et al., 1983), we demonstrated that $S$. dublin strains from cattle harboured a characteristic $50 \mathrm{MDa}$ plasmid and suggested that this plasmid plays an important role in the virulence of $S$. dublin, since the loss of the plasmid resulted in the loss of virulence for mice. Several workers (Baird et al., 1985; Chikami et al., 1985; Heffernan et al., 1987; Helmuth et al., 1985; Manning et al., 1986) have also reported that a similar plasmid was associated with the virulence of $S$. dublin. Although their precise function(s) have not been elucidated, other virulence-associated plasmids have been reported in several serotypes of Salmonella such as $S$. typhimurium (Baird et al., 1985; Hackett et al., 1987; Helmuth et al., 1985; Jones et al., 1982; Michiels et al., 1987; Pardon et al., 1986), S. enteritidis (Helmuth et al., 1985; Nakamura et al., 1985), S. choleraesuis (Helmuth et al., 1985; Kawahara et al., 1988) and S. gallinarum (Barrow et al., 1987).

During our investigations on the role of the 50 MDa plasmid of $S$. dublin in pathogenicity, we observed that resistance to rabbit and guinea-pig serum in $S$. dublin was mediated by the plasmid. In Gram-negative pathogens serum resistance is considered to be an important virulence factor conferred either by lipopolysaccharides (LPS) or by protein components of the outer membrane (Buchanan \& Pearce, 1971). This prompted us to analyse the composition of the LPS in $S$. dublin. This paper deals with the serum resistance, and the changes in the composition of $S$. dublin LPS, associated with the presence of the $50 \mathrm{MDa}$ plasmid. 
Table 1. Bacterial strains and plasmids used

$\begin{array}{lll}\begin{array}{l}\text { Strain/plasmid } \\ \text { S. dublin }\end{array} & \text { Relevant characteristics } & \text { Source/reference } \\ 5240 & \text { Wild-type, pTE800 } & \text { Terakado } \text { et al. (1983) } \\ \text { C524 } & \text { pTE800-cured } & \begin{array}{l}\text { This work } \\ \text { This work }\end{array} \\ \begin{array}{l}\text { E. coli } \\ \text { TH471 }\end{array} & \text { C542(pTE8001) } & \\ \text { Plasmids } & \text { pTH10 } & \text { Harayama } \text { et al. (1980) } \\ \text { pTE800 } & \text { 50 MDa plasmid from } S . \text { dublin } & \text { Terakado et al. (1983) } \\ & \text { 5240, non-conjugative } & \\ \text { pTE8001 } & \text { 50 MDa::Tn1, non-conjugative } & \text { This work }\end{array}$

\section{METHODS}

Bacterial strains and plasmids. These are listed in Table 1. The virulent wild-type strain 5240 was isolated from a field outbreak of bovine salmonellosis (Terakado et al., 1983). The derivative strain C524, cured of its plasmid (pTE800), was obtained from strain 5240 after treatment with ethidium bromide ( $700 \mu \mathrm{g} \mathrm{ml}^{-1}$ in L broth). Strain 5241 was constructed by transformation of C524 with pTE8001 (a plasmid derived from pTE800 by insertion of $\operatorname{Tn} 1)$. Antigenic analysis of these three strains showed that C524 and 5241 possessed $\mathrm{O}(9,12)$ and $\mathrm{H}(\mathrm{g}, \mathrm{p}:-)$ antigens identical to those of the parental strain 5240 .

Media. Nutrient broth (Difco) and L broth [10 g tryptone (Difco), 5 g yeast extract (Difco), $1 \mathrm{~g}$ glucose, $5 \mathrm{~g} \mathrm{NaCl}$ per litre, pH 7.4] were used as liquid media. Trypticase soy agar (BBL) and L agar [15 g Bacto-agar (Difco) per litre of $\mathrm{L}$ broth] were used as solid media.

Plasmid analysis. Small-scale isolation of plasmid DNA was done by the method of Birnboim \& Doly (1979). Large-scale preparation of plasmid DNA was done by $\mathrm{CsCl} /$ ethidium bromide density-gradient ultracentrifugation at $140000 \mathrm{~g}$ for $15 \mathrm{~h}$ at $20^{\circ} \mathrm{C}$ in a Beckman VTi 65 rotor. Horizontal electrophoresis was done in $0.8 \%(\mathrm{w} / \mathrm{v})$ agarose gels using Tris/borate buffer ( $89 \mathrm{~mm}$-Tris, $2.5 \mathrm{~mm}$-EDTA, $8.0 \mathrm{~mm}$-boric acid, pH 8.4). DNA was usually electrophoresed for $5 \mathrm{~h}$ at a constant voltage of $100 \mathrm{~V}$. The restriction enzymes HindIII and EcoRI were obtained from Takara Shujo Co. Plasmid DNA was digested as recommended by the supplier.

Tagging of S. dublin plasmid with Tn1. The method for labelling the plasmid with $\operatorname{Tn} 1$ was essentially as previously reported (Danbara et al., 1987). For the tagging of the $50 \mathrm{MDa}$ plasmid with $\mathrm{Tn} I$ as a selective marker, a thermosensitive mutant of RP4, pTH10 (Harayama et al., 1980), into which a 3.3 MDa ampicillin-resistance transposon $\operatorname{Tn} l$ had been inserted, was conjugatively introduced into strain 5240 and the transconjugants were grown at $42{ }^{\circ} \mathrm{C}$ in the presence of ampicillin. The transconjugants resistant to ampicillin but susceptible to kanamycin and tetracycline were selected after $42^{\circ} \mathrm{C}$ incubation, because pTH10 contains genes encoding resistance to ampicillin, kanamycin and tetracycline. The transposition of $\mathrm{Tn} l$ into the $50 \mathrm{MDa}$ plasmid was confirmed by an increase in the size of the original plasmid by $3.3 \mathrm{MDa}$.

Reintroduction of the plasmid into the cured strain. The plasmid tagged with $\mathrm{Tn} I$ was reintroduced into $\mathrm{C} 524$ by transformation, because the plasmid was not conjugative. Competent cells were prepared by the rubidium chloride method (Kushner, 1978). A $200 \mu 1$ volume of the competent cells was mixed with $2 \mu \mathrm{g}$ plasmid DNA in $20 \mu \mathrm{l} \mathrm{TE}$ buffer (10 mM-Tris/ $\mathrm{HCl}, 1 \mathrm{~mm}$-EDTA, pH 8.0) and the mixture was agitated for $3 \mathrm{~min}$ at $42^{\circ} \mathrm{C}$ after cooling on ice for $30 \mathrm{~min}$. It was then added to $2.5 \mathrm{ml} \mathrm{L}$ broth, incubated for $6 \mathrm{~h}$ at $35^{\circ} \mathrm{C}$ with gentle shaking, and then spread on $\mathrm{L}$ agar containing ampicillin $\left(25 \mu \mathrm{g} \mathrm{ml}^{-1}\right)$. Colonies that grew at $37^{\circ} \mathrm{C}$ were isolated.

Serum resistance. Sera from New Zealand White rabbits, whose complement components are genetically determined (Komatsu et al., 1985), were used for the assay of bactericidal activity. Two types of sera, with the following characteristics, were used: (a) the levels of the third (C3) and eighth (C8) components of complement in the serum were normal $\left(\mathrm{C} 3,1 \mathrm{mg} \mathrm{ml}^{-1} ; \mathrm{C} 8,80 \mu \mathrm{g} \mathrm{ml}^{-1}\right)$; and $(b)$ the level of $\mathrm{C} 3$ was normal but that of $\mathrm{C} 8$ was deficient $\left(0 \mu \mathrm{g} \mathrm{ml}^{-1}\right)$. These sera were given by Dr M. Komatsu and were kept at $-80^{\circ} \mathrm{C}$ until use. Bacteria from an early-exponential-phase broth culture were washed twice with phosphate-buffered saline $(0.15 \mathrm{M}-\mathrm{NaCl}, 10 \mathrm{mM}$ sodium phosphate buffer, pH 7.2; PBS) and diluted 1000-fold in PBS, in a multiwell tissue-culture plate (Sumitomo Chemical Laboratories). Samples $(10 \mu \mathrm{l})$ of this dilution (approximately $10^{4}$ organisms) were added to $90 \mu \mathrm{l}$ of serum and incubated at $37^{\circ} \mathrm{C}$. Percentage survival was calculated as the ratio of the bacterial count after $1 \mathrm{~h}$ to the count at zero time, multiplied by 100 . The experiments were repeated three times and the results were expressed as geometric means \pm standard deviations.

Analysis of neutral sugars in LPS. LPS was extracted from $500 \mathrm{ml}$ of overnight $\mathrm{L}$ broth culture and purified by the method of Westphal \& Jann (1965). The neutral sugars in the LPS were estimated by gas-liquid chromatography (GLC) after hydrolysis for $4 \mathrm{~h}$ at $100^{\circ} \mathrm{C}$ with $1 \mathrm{M}-\mathrm{HCl}$ and conversion into trimethylsilyl derivatives (Sweeley $e t$ al., 1963). GLC was performed on a Hewlett-Packard model 5880A gas chromatograph fitted with a flame 
Table 2. Molar ratios of neutral sugars in LPS of S. dublin strains

Symbols for sugars: Rha, rhamnose; Man, mannose; Gal, galactose; Glu, glucose; Tyv, tyvelose; Hep, heptose. Monosaccharides were estimated by GLC. (see Methods).

$\begin{array}{clccrccc}\text { Strain } & \text { Plasmid } & \text { Rha } & \text { Man } & \text { Gal } & \text { Glu } & \text { Tyv } & \text { Hep } \\ 5240 & \text { pTE800 } & 9 \cdot 1 & 8 \cdot 5 & 11 \cdot 5 & 4.9 & 4.5 & 1.0 \\ \text { C524 } & \text { Cured } & 2 \cdot 0 & 2 \cdot 2 & 5 \cdot 8 & 4 \cdot 0 & 0.6 & 1.0 \\ 5241 & \text { pTE8001 } & 7.9 & 8.5 & 11 \cdot 0 & 3 \cdot 3 & 4 \cdot 2 & 1.0\end{array}$

ionization detector. The separations were carried out on a flexible fused capillary column coated with methylsilicone SP2100 (Hewlett Packard). The column temperature was programmed at $2.5^{\circ} \mathrm{C} \mathrm{min}^{-1}$, from $195^{\circ} \mathrm{C}$ to $250^{\circ} \mathrm{C}$. The amounts of neutral sugars in the LPS were calculated as molar ratios relative to heptose.

\section{RESULTS}

Reintroduction of the $50 \mathrm{MDa}$ plasmid tagged with Tnl into the cured strain. The $50 \mathrm{MDa}$ plasmid from $S$. dublin strain 5240, designated pTE800, was cleaved by HindIII into 9 fragments, and by $E c o$ RI into 10 fragments. In the Tn 1 tagging experiments, several kinds of $50 \mathrm{MDa}$ plasmids into which $\mathrm{Tn} l$ had been inserted were obtained. One of them, designated pTE8001, into which Tnl was inserted in HindIII cleavage fragment 3, was selected and reintroduced into the cured strain C 524 by transformation. One of the purified transformants obtained was designated as 5241 and used for further experiments.

Serum resistance. In C3-normal but C8-deficient serum, there was no significant difference in viable numbers between the wild-type strain 5240, the plasmid-cured strain C524 and the plasmid-reintroduced strain 5241. All of them showed an increase in viable numbers after culture for $1 \mathrm{~h}$ at $37^{\circ} \mathrm{C}$, with percentage survival values of $153.4 \pm 15.7$ for strain 5240 , $138.0 \pm 20.0$ for strain C524 and 192.5 \pm 7.6 for strain 5241 (means of three experiments \pm SD). In contrast, there was a marked difference in the C3-normal and C8-normal serum. In this serum, strain C524 showed a marked decrease after culture for $1 \mathrm{~h}$ at $37^{\circ} \mathrm{C}$, and viable numbers were less than $10^{2}$ organisms per $100 \mu$ l of mixed culture (less than $1 \%$ survival). A slight decrease in viable numbers was also observed in both plasmid-positive strains 5240 and 5241 (percentage survival $52 \cdot 5 \pm 9 \cdot 2$ and $90 \cdot 4 \pm 4 \cdot 0$, respectively), but reduction rates were much lower than that of strain C524, indicating that the reintroduction of pTE8001 into the cured strain restored serum resistance.

Composition of neutral sugars in LPS. The composition of the neutral sugars in LPS preparations obtained from the three $S$. dublin strains was determined by GLC (Table 2). In the plasmid-cured strain C524, the molar ratios of almost all the sugars were decreased compared with the parent strain 5240, the greatest reduction (by more than $80 \%$ ) being recorded for tyvelose. In contrast, the molar ratios in the plasmid-reintroduced strain 5241 were close to those of the wild-type, except for glucose.

\section{DISCUSSION}

Serum resistance seems to be an important virulence factor in invasive serotypes of Salmonella, since it promotes survival of the organisms. Plasmids associated with serum resistance have been reported in several bacteria such as Escherichia coli (Binns et al., 1982; Moll et al., 1980) and S. typhimurium (Hackett et al., 1986). More recently, Hackett et al. (1987) have cloned the gene responsible and reported that serum resistance in $S$. typhimurium is mediated by an $11 \mathrm{kDa}$ polypeptide encoded by a $2.1 \mathrm{~kb}$ fragment. Helmuth et al. (1985) reported that only plasmid-positive strains of $S$. dublin were resistant to the bactericidal activity of guinea-pig serum, although they were not able to reintroduce the plasmid into strains lacking the plasmid.

The present study demonstrated that curing strain 5240 of $S$. dublin of the $50 \mathrm{MDa}$ plasmid resulted in high susceptibility to $\mathrm{C} 3$-normal rabbit serum compared with that of the wild-type parent strain. In contrast, the survival rate of the plasmid-reintroduced strain was significantly 
increased in such serum, indicating that serum resistance in $S$. dublin is associated with the presence of the $50 \mathrm{MDa}$ plasmid. Moreover, a similar correlation was observed in our previous experiments on the virulence of the strain for mice (data not shown). When the C8-deficient serum was used for the assay of bactericidal activity, however, no such difference in viable numbers was observed among $S$. dublin strains examined. This finding seems to be reasonable, because $\mathrm{C} 8$ plays an important role in the cell membrane attack mechanism and complementmediated cell lysis (Stolfi, 1968).

Alterations in the sugar composition of LPS have been reported in S. typhimurium infected with a derepressed ColIb mutant plasmid or an R64-11 plasmid, also derepressed in their transfer (Derylo et al., 1975). Bacteria carrying such plasmids showed a marked decrease in amounts of neutral sugars in the LPS, while bacteria carrying the wild-type ColIb, or the revertant of a $d r d$ mutant to the wild-type, showed increased amounts of sugar. However, the non-colicinogenic strain resulting from the elimination of such a $d r d$ mutant plasmid showed no changes in the sugar composition of the LPS (Derylo et al., 1975). These results suggest that the mechanism of changes in the sugar composition of the LPS mediated by such $d r d$ mutant plasmids might be different from that mediated by the $50 \mathrm{MDa}$ plasmid of $S$. dublin. As to genetic properties, the $50 \mathrm{MDa}$ plasmid of $S$. dublin exhibited fertility inhibition and belonged to incompatibility group FII (unpublished data).

Although the mechanism of changes in sugar composition mediated by the $50 \mathrm{MDa}$ plasmid is unknown, it is interesting that, in our experiments, such changes were correlated with changes in survival rates of $S$. dublin strains in C3-normal serum. Recently, Grossman et al. (1987) reported that the size and distribution of LPS determine serum resistance in $S$. montevideo. On the other hand, Hackett et al. (1987) reported that a plasmid-cured $S$. typhimurium strain did not express normal LPS, but introduction of the gene for an $11 \mathrm{kDa}$ protein into the strain rendered it serum resistant without restoration of normal LPS synthesis. Heffernan et al. (1987) have reported that the biological function of the plasmid of $S$. dublin appears to be to act primarily at the level of the reticuloendothelial system and possibly to destroy tissue macrophages. To elucidate the precise functions and gene products of the $50 \mathrm{MDa}$ plasmid of $S$. dublin will require the cloning of the gene(s) determining serum resistance. This is now in progress.

This study was supported by grant A12601 provided by the Ministry of Education, Science, and Culture of the Japanese government.

We thank Professor M. Yoshikawa, Institute of Medical Science, University of Tokyo, and Dr M. Komatsu, National Institute of Animal Husbandry, for supplying E. coli TH471 and rabbit sera. We also thank Mr Y. Mukohara, Mr K. Koiwa and Mr T. Nakano for technical assistance.

\section{REFERENCES}

Baird, G. D., Manning, E. J. \& Jones, P. W. (1985). Evidence for related virulence sequences in plasmids of Salmonella dublin and Salmonella typhimurium. Journal of General Microbiology 131, 1815-1823.

Barrow, P. A., Simpson, J. M., Lovell, M. A. \& BinNs, M. M. (1987). Contribution of Salmonella gallinarum large plasmid toward virulence in fowl typhoid. Infection and Immunity 55, 338-392.

BinNs, M. H., MAYden, J. \& Levine, R. B. (1982). Further characterization of complement resistance conferred on Escherichia coli by the plasmid genes traT of R100 and iss of ColV, I-K94. Infection and Immunity 34, 654-659.

BiRnBoIm, H. C. \& Doly, J. (1979). A rapid alkaline extraction procedure for screening recombinant DNA. Nucleic Acids Research 7, 1513-1523.

Buchanan, T. M. \& Pearce, W. A. (1971). Pathogenic aspects of the outer membrane components of gramnegative bacteria. In Bacterial Outer Membranes, pp. 475-514. Edited by M. Inoue. New York: John Wiley.

ChikAMi, G. K., Fierer, J. \& Guiney, D. G. (1985). Plasmid-mediated virulence in Salmonella dublin demonstrated by use of a Tn5-oriT construct. Infection and Immunity 50, 420-424.

Danbara, H., Komase, K., KiriI, Y., Shinohara, M., Arita, H., Makino, S. \& Yoshikawa, M. (1987). Analysis of the plasmids of Escherichia coli O148:H28 from travellers with diarrhea. Microbial Pathogenesis 3, 269-278.

Derylo, M., Glowacka, M., Lorkiewicz, Z. \& RussA, R. (1975). Plasmid-determined alterations of Salmonella typhimurium lipopolysaccharides. Molecular and General Genetics 140, 175-181. 
FIERER, J. (1983). Invasive Salmonella dublin infections associated with drinking raw milk. Western Journal of Medicine 138, 665-669.

Grossman, N., Schmetz, M. A., Foulds, J., Klima, E. N., Jiminez, V., Leive, L. L. \& JoINER, K. A. (1987). Lipopolysaccharide size and distribution determine serum resistance in Salmonella montevideo. Journal of Bacteriology 169, 856-863.

Hackett, J., Kotlarski, I., Mathan, V., Francki, K. \& Rowley, D. (1986). The colonization of Peyer's patches by a strain of Salmonella typhimurium cured of the cryptic plasmid. Journal of Infectious Diseases 153, 1119-1125.

Hackett, J., Wyk, P., Reeves, P. \& Mathan, V. (1987). Mediation of serum resistance in Salmonella typhimurium by an 11-kilodalton polypeptide encoded by the cryptic plasmid. Journal of Infectious Diseases 155, 540-549.

Harayama, S., Tsuda, M. \& IINo, T. (1980). High frequency mobilization of the chromosome of Escherichia coli by a mutant of plasmid RP4 temperature-sensitive for maintenance. Molecular and General Genetics 180, 47-56.

Heffernan, E. J., Fierer, J., Chikami, G. \& Guiney, D. (1987). Natural history of oral Salmonella dublin infection in BALB/c mice: effect of an 80-kilobasepair plasmid on virulence. Journal of Infectious Diseases 155, 1254-1259.

Helmuth, R., Stephan, R., Bunge, C., Hoog, H., SteINBECK, A. \& Bulling, E. (1985). Epidemiology of virulence-associated plasmids and outer membrane protein patterns within seven common Salmonella serotypes. Infection and Immunity 48, 175182.

Jones, G. W., Rabert, D. K., Svinarich, D. M. \& Whitfield, H. J. (1982). Association of adhesive, invasive, and virulent phenotypes of Salmonella typhimurium with autonomous 60-megadalton plasmids. Infection and Immunity 38, 476-486.

Kawahara, K., Haraguchi, Y., Tsuchimoto, M., TERAKADO, N. \& DaNbara, H. (1988). Evidence of correlation between 50-kilobase plasmid of Salmonella choleraesuis and its virulence. Microbial Pathogenesis 4, 155-163.

Komatsu, M., Yamamoto, K., Kawashima, T. \& Migita, S. (1985). Genetic deficiency of the $\alpha-r-$ subunit of the eight complement component in the rabbit. Journal of Immunology 134, 2607-2609.

KUSHNER, S. R. (1978). An improved method for transformation of Escherichia coli with ColE1derived plasmids. In Genetic Engineering, pp. 17-23. Edited by H. W. Boyer \& S. Nicosia. Amsterdam: Elsevier.
Manning, E. J., Baird, G. D. \& Jones, P. W. (1986). The role of plasmid genes in the pathogenicity of Salmonella dublin. Journal of Medical Microbiology 21, 239-243.

Michiels, T., Popoff, M. Y., DurviauX, S., CoynAULT, C. \& CoRnElis, G. (1987). A new method for the physical and genetic mapping of large plasmids: application to the localisation of the virulence determinants on the $90 \mathrm{~kb}$ plasmid of Salmonella typhimurium. Microbial Pathogenesis 3, 109-116.

Moll, A., Manning, P. A. \& Timmis, K. N. (1980). Plasmid-determined resistance to serum bactericidal activity: a major outer membrane protein, the traT gene product, is responsible for plasmid-specified serum resistance in Escherichia coli. Infection and Immunity 28, 359-367.

Nakamura, M., Sato, S., Ohya, T., Suzuki, S. \& IKEDA, S. (1985). Possible relationship of a 36megadalton Salmonella enteritidis plasmid to virulence in mice. Infection and Immunity 47, 831-833.

Pardon, P., PopofF, M. Y., Coynault, C., Marly, J. \& MiRAs, I. (1986). Virulence-associated plasmids of Salmonella serotype typhimurium in experimental murine infection. Annales de microbiologie 137B, 4760.

Small, R. G. \& Sharp, J. C. M. (1979). A milk-borne outbreak due to Salmonella dublin. Journal of Hygiene 82, 95-100.

STOLFI, R. L. (1968). Immune lytic transformation: a state of irreversible damage generated as a result of the reaction of the eighth component in the guinea pig complement system. Journal of Immunology 100, 46-54.

Sweeley, C. C., Bentley, R., Makita, M. \& Welis, W. W. (1963). Gas-liquid chromatography of trimethylsilyl derivatives of sugars and related substances. Journal of the American Chemical Society 85, 2497-2507.

Terakado, N., Sekizaki, T., Hashimoto, K. \& NAITOH, S. (1983). Correlation between the presence of a fifty-megadalton plasmid in Salmonella dublin and virulence for mice. Infection and Immunity 41, 443-444.

WALton, J. R. (1972). Bacteriological, biochemical and virulence studies on Salmonella dublin abortion and enteric disease in cattle and sheep. Veterinary Record 90, 236-240.

WESTPHAL, O. \& JANN, K. (1965). Bacterial lipopolysaccharides. Extraction with phenol-water and further applications of the procedure. Methods in Carbohydrate Chemistry 5, 83-91. 